制癌剂の担癌体に及ぼす影整に関する研究

$615.771 .7: 616.006 .6$

制癌拜の担癌体に及ぼす影響に関する研究

第 3 編

担癌体に対する制癌剂投与時の網内系機能に関する実験的研究

（本研究は文部省科学研究費の補助による）

（本論文の要旨は第20回日本癌学会総会. 第62回日本外科学会総会において発表した）

岡山大学医学部第 1 外科教室（指導：陣内傳之助教授）

学学管龟山 英之

[昭和 37 年 7 月 18 日受稿]



第1章 粕言ならびに文献

现在の制瘦剂は，多くは細胞分裂表であるが，腫 煌細胞を破罗する反面, 正常細胞にも強い侵裂を与 え，腫湯の治療にあたり，かえつて生体に不利を招 くことがあることは周知の事実である，最近癌患者 飞抗癌性化学療法を行なうと, 汃えつて Adverse Effects のため死期を早めるという見解も少なくな い. 德山らり癌化学療法の再認識という見地よ り意見をのへており，手術不能の晚期癌の場合は， 患者はすでに悪液質になつており，生体機能が破諚 におちいつているので，何らの前準備もなく制癌剂 を使用したのでは，加えつて悪化を招き死期を早め ることがあり得るとのへている，盛田2)は Nitromin, TEM, Sarkomycin, Carzinophilin, Azan は その程度の差はあるが，何れも連用すれば全身免度 力を低下せしめ, 畽瘍の発育に好条件を与えるとの へ，近藤らうは Nitromin 投与により吉田肉腫の転 移形成が，かえつて促進される場合のあるととを串

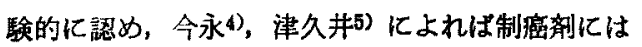
增癌作用があり，一方宿主の抵抗性を弱めるととも

\begin{abstract}
次
放射能の時間的変化

第 2 飾 血清鉄コロイド ${ }^{59} \mathrm{Fe}$ 静注後の各塔器 における $69 \mathrm{Fe}$ の分布

第3 節 血清鉄コロイド ${ }^{69} \mathrm{Fe}$ 静注後の肝非へ ミン鉄
\end{abstract}

第 4 節 腫湯の発育の消長

第 4 章 総括ならびに考按

第 5 章 結諭

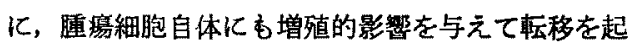
てし易くするとのへている，乙の上うに制癌剂仙は 睡湯の発育を阻止したり，それを破壤したりする反


を促すととああり得るわけである．悪性厘場の手術 において，今日なお再発の多く見られるのは，術後 腫場細胞が䧟残するためでああろうが，むう一つの 理由は生体に腫㿇発育阻止の力が不足しているから である.

Baillif(6), Halpern7), Thorel18), Bollag9), Stern'10), などは, 腫㴡の発䏍と網内系との関係について興味 深い報告を行なつているか，Stern10)は生体に戈け ろ盾㰾発育は局所および全身の網内系の disorder に支配されるとしている。このように悪性腫湟の発 育之網内系绕能との間には，密接な関係が考えら れ, 睡瘍の発青阻止には網内系が大いに関係してい ることが知られている. 制癌剂を投与した場合の Adverse Effects бこの網内系機能の減退に負うと とろが多いのではないかと考えられる。

そこで本編では，腫瘍の增殖やてれ対する制癌 剂投与が，網内系機能にどのよう亿影幚するかを検 
討することによつて，制䗗剂投与時の副作用防止の 指針が得られるかあ知れないと考え，ての研觉を行 なつたわけである.

しかし従来の網内系㙨能測定法としては, AdlerReimannによるコンゴロート法が過去における唯 一の方法であつた，コンゴロート，料，金銀コロ イドなどは、生体にとつて買物の粒子であり、これら 粒子を静注し，その貪喰機能のみをもつて網内系哓 能を観察しようとすることは，嚑内系機能の一面の みを示す方法といわねばならない，私はさらに一歩 進めて投与された柆子が貪喰されたあと網内系で生 合成されて生体構成要点の中に自然の姿で incorporate してゆく網内系機能の他の一面をも同時に検 することが重要であるとの考えから，血清鉄コロイ ド ${ }^{59 \mathrm{Fe}}$ を用いて，絧内采の貪喰能と鉄合成璣能と を同時観察しうる妹㞎，小林法11を用いること にしだ.

\section{第 2 章 実倹方法}

\section{第 1 節 実䤅動物}

笑験怔物としては健康な $80 \sim 100 \mathrm{~g}$ の市販ラッテ を用い，オリエンタル醉母製の実験用固型飼料 MF および生鮮野菜とをすつて飼育した，実験前準借飼 育期間は 7 日以上とした。

\section{第 2 管 実 鋻 材料}

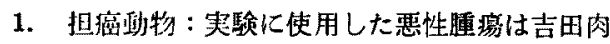
腫12)で本学媳源研究所上り分与されたものである. 使用比当つては教室においてラッテ腹㓐内継代移植 を行ない，腹北移植後 5 ないし7日目の純培荃状態 にある腹水 $5 \times 10^{7} \mathrm{Cell} / \mathrm{cc}$ を $0.2 \mathrm{cc}$ 実験 ラッテ 背部皮下に移植し, 议下結節型とした（以下 $\mathrm{Y} \cdot \mathrm{s}$ と略す)。

2. 制澏剂：投与した制癌剂は㙝和酸酸工業株式 会社の提供による Mitomycin C (以下MC と略す) で, 所用量を生理的食塩水で桸积し，投与法はすへ て腹腔内注射とした。

3. 放射性血清鉄コロイド： ${ }^{59} \mathrm{Fe}$ でラベルした 血清三洒鉄コロイドすなわ血清鉄コロイド ${ }^{69} \mathrm{Fe}$ (以下 S. ${ }^{69} \mathrm{Fe}$. C. と略す) は, 次にのへる方法化 より作製し，ラッテの尾静脈より正確化 1 回 $2.0 \mathrm{cc}$ を注射した．S. ${ }^{59} \mathrm{Fe}$. C. は，健康ラッテより血清 $8.0 \mathrm{cc}$ をと, $\mathrm{FeCl}_{3}$ 海液 $(\mathrm{Fe} \cdots 10 \mathrm{mg} / \mathrm{cc}$, 塩酸酸 性）の $0.5 \mathrm{cc}$ と ${ }^{59 \mathrm{Fe}}$ を $25 \mu \mathrm{c}$ 含むと乙ろの微量 の $\mathrm{FeCl}_{3}$ 溶液とをよく混和し，血清を十分筧拌し ながら，との混合液を血清中に Flocke をできるだ
け作らない上うに徐々に當下し，その後 $\mathrm{pH}$ をあ げるため $3 \% \mathrm{Na}_{2} \mathrm{CO}_{3}$ 溶液を徐々に滴下して十分混 和して, 最終 $\mathrm{pH}$ を 7.2 7.3に至らしめれば,清 澄な軟結合性血清鉄コロイド液がえられる。このよ うにして作つた嗏液に血清を若干追加すれば，全量 $10.0 \mathrm{cc}$ となる，かくしてでき上つた S. $59 \mathrm{Fe} . \mathrm{C}$. 液は $\mathrm{Fe} \cdots 50 \mathrm{mg} \mathscr{0}$ で, $\mathrm{Fe} \cdots=0.5 \mathrm{mg} / \mathrm{cc}, 69 \mathrm{Fe}=2.5$ $\mu \mathrm{c} / \mathrm{cc}$ である.

4. アイントープ: ${ }^{69} \mathrm{Fe} \mathrm{Cl}_{3}$ 溶液は Oak Ridge National Laboratory 製のラジオアイソトープ $59 \mathrm{Fe}$ $\mathrm{Cl}_{3}$ を用いた．本品は熄酸酸性で Normality 1.90 Acid, Chemical Form $\mathrm{FeCl}_{3}$ in HCl. Sol., Batch No. 245, Concentration $3.67 \pm 5 \% 6 \mathrm{mc} / \mathrm{ml}$, Specific Activity $9061 \mathrm{mc} / \mathrm{g}, 65 \mathrm{Fe} 0.024 \mathrm{mc} / \mathrm{ml}, \mathrm{Fe} \cdots 0.405$ $\mathrm{mg} / \mathrm{ml}, 60 \mathrm{Co} 0.00136 \mathrm{mc} / \mathrm{ml}$ で 1961年 4 月22日に 検定したものである、私はこれを 5 月より 8 月の間 に実駼に使用し，使用量は半減期より計算したちの である.

5. 测定器：放射能测定器は神戸工業製の Scintillation Counter Mount Model EA-13 を使用 し，次の実験方法でのへるように血液湴通型で 5 分問，その他はウエル型で 1 分間測定し，自然係数 はすべて差引いて計算した。

\section{第3節 実験方法}

$80 \mathrm{~g}$ から $100 \mathrm{~g}$ までのラッテ5ないし 7 匹を 1 群 として, 次の 6 群比分けた。

第 1 群：正常ラッテ6匹を用い，MC 投与も吉田 肉腫艾下移植をす行なわず，S. 59Fe。．．のみを $2 \mathrm{cc}$ 静注した対照群.

符 2 群：正常ラッテ7匹を用い，MC $200 \mathrm{mcg} / \mathrm{kg}$ /day 4 日連続投与し，5 日目に S. 59 Fe.C. を $2 \mathrm{cc}$ 静注した群.

第 3 群 : 正常ラッテ 5 匹を用い, MC $500 \mathrm{mcg} / \mathrm{kg}$ /day を 4 日連続投与し， 5 日目に S. 99Fe. C. を 2 cc 静注した群.

第 4 群：ラッテ 5 匹を用い，背部皮下に吉田肉腫 を移植し皮下結節型となし，9日目に S. $69 \mathrm{Fe}$. C. を $2 \mathrm{cc}$ 静注した群.

第 5 群：吉田肉腫皮下移植後 5 日目より MC 200

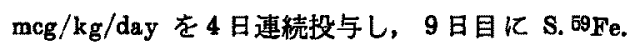
C. を $2 \mathrm{cc}$ 静注した群.

第 6 群：吉田肉厘皮下移植後 5 日目より MC 500 $\mathrm{mcg} / \mathrm{kg} / \mathrm{day}$ 日連秸投与し，9日目に s. $59 \mathrm{Fe}$. C. を 2 cc 静注した群。

勺上 6 群について, S. ${ }^{69 F e}$. C. 静注後 $2,6,12$, 
24, 48.72の各時間に経時的に，日血㻌定ザーリ 一用メランジュールで $0.02 \mathrm{cc}$ の末梢血をとり,


ンプを作り，乾燥後その放射能を Scintillation Counter 普通型で 5 分間測定した，測定後は，この 娍紙スタンプを $\mathrm{X}$ 線フィルムに10 日間露出して, 小林11)による Spot Paper Autoradiography を行 なつた（写真 $1,2,3,4,5,6$ ).

また S. 的Fe. C. 静注後 72 時間でラッテを屠殺 解剖し, 各㖑器を採取して $1 \mathrm{~g}$ 当りの放射能をウエ ル型で 1 分間測定した。 ただラッテの骨加らは，骨 髄が得られにくいので，右大腿骨を採り出して骨皮


ラスホモゲナイザーで肝のホモヂネートを作り， Bruckmann の吉野変法13) とより総非へミン鉄を, 中島法14ににより Ferritin 鉄を分画抽出し，両者を 同一条件でその放射能をウエル型で 1 分間測定した。 また担癌ラッテでは，畽埸移植日より4 日目から年 日屠殺日まで腫場の大きさをノギスをもつて縦およ び横徍を計則し，ての平均值をもつて腫埸の発育。 あるいは縮小の度合を示すこととした。

\section{第 4 節 肝䑏鉄測定法}

滕器の鉄定量法には, Bruckmann \& Zondek (5), 米山・紺野法16)，吉野変法13)，中島法14)などがあ るが、私は吉野変法13) で総非へミン鉄を，中島 法14)により Ferritin を分画して测定した. 次にの べる試楽は，すへてて化学用最純品特級を用い，鉄の 含まれてないことを確認し, 試薬の調製には再蒸溜 水を使用した。またガラス器具は，すべてクローム 硫酸および浱塩酸にそれぞれ一尽夜つけ，一尽依流 水中で水洗したのち, 再蒸溜水で十分洗涤し, 清潔 なガーゼで包んで乾燥したものを用いた。

1. 試㭗わよび器具

a) 飽和ピロ橉酸ソーダ溶液 (4

b) 1096 お上び2096 の三盐化醋酸溶液

c) $3.5 \%$ 塭酸

d）塩酸および再蒸留水で洗滌乾燥した硬質ガラ ス

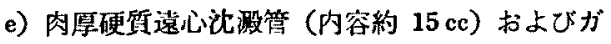
ラス棒

f) $2.0 \mathrm{cc}, 3.0 \mathrm{cc}, 4.0 \mathrm{cc}$ のフォルピペット. 1.0 cc のオストワルド氏ピペット.

2. 分劃惻定法

a）総非へミン鉄測定法

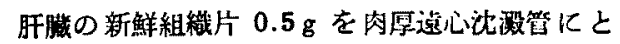

り. 粉末ガラス $0.2 \mathrm{~g}$ を混入し,ガラス棒で碎㛗 し泥状となし，飽和ピロ燐酸ンーダ溶液 $2.0 \mathrm{cc}$ を 加え十分に罯拌後，10\%の三塩化醋酸 $3.0 \mathrm{cc}$ を追 加してょく混和する，遠沈管をアルミ箱でおおい煮 洲中に可及的正確に 7 分間加温し, 放冷後 3000 回 転 15 分間遠沈して上清 $2.0 \mathrm{cc}$ を別の試験管にと つて，その放射能を測定した。

b) Ferritin 测定法

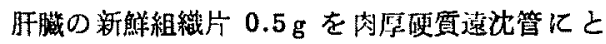
り，a）と同椂江确挫し泥状としたものに再登溜水 $4.0 \mathrm{cc}$ を加え，よく㨨拌後，遠沈管をアルミ簿 でおおい， $80^{\circ} \mathrm{C}$ の水浴中で 5 分間加熱する. 放 冷後 3000 回䎐 15 分間遠沈し, 上清 $2.0 \mathrm{cc}$ を他 の遠沈管に移して $3.5 \%$ 塩酸 $1.0 \mathrm{cc}$ を加え, 惹沸 中で可及的正確に 7 分間加熱する. 放冷後 $20 \%$ 三 盐化醋酸 $1.0 \mathrm{cc}$ を加え, 3000 回転 15 分間遠沈し, 上清 $2.0 \mathrm{cc}$ を別の試験管にとり，二の放射能を測 定した.

\section{第3 章 実略成耧}

\section{第 1 匴 血清鉄コロイド ${ }^{59 F e}$ 静注後の末梢 血放射能の時間的変化}

写其1 6 沙第 1 群より第 6 群までの 6 群に S. ${ }^{59} \mathrm{Fe}$. C. を静注した後の末悄血の経時的 Spot Paper Autoradiographである. 写点の Spotをみ ると, ${ }^{59} \mathrm{Fe} は 12$ ないし 24 時間で減少し（初期 頜喰による)，72 時間で増加している ${ }^{59} \mathrm{Fe} の \mathrm{Hb}$ 内への incorporation）ことが一目膫然である。第 1 群の 6 匹はいつれる 12 時間で最低となり，24 時 間ではすでに Hb 合成が起りはじめている.第 2 群の 7 匹では，48 時間目加ら $\mathrm{Hb}$ 合成が起つてお り，明らかな合成遮延が示されている。第 3 群の 5 匹では，72 時間目からようやく合成がみられる程 亿強度の合成遅延がみられる No.41 を含み，一般 飞第 2 群より毛強い合成还延が証明された。第 4 群 の 5 匹では，第 1 群よりやや合成幄延がみられ，24 ないし 48 㭙間より合成が開始されている。 この中 No. 53 および No. 55 の 2 匹は大巾の合成逮延がみ られ，48洔閉ないし 72 時䏎で合成が開始されてい る。第 5 样では，24将間目より合成が開始さ机て いるが, No. 62 は明ら加な合成通延を示している。 籍 6 群では 5 匹ともに24時䦌目より合成が開始さ れ，対照群の第 1 群に近い成綨が示された。しかし 全群とも賈喰の点では有意の差を見分けることは不 可能である. また血液 Spotの Scintillation Counter 
測定做を表示すれば，第 1 表のでとくである。なお カゥント変勒率は次のどとく定めて計算した。

カウント変動率 $=\frac{\text { 各時間のカウント }-2 \text { 時間目の }}{2 \text { 時間目のカ }}$

$\frac{\text { カウント }}{\text { ウント }} \times 100$

またカウント変動率の平均値を 596 の危除率で求 め，その平均值を洔閤的経過により图示すれば，第 1 図および第 2 図のでとくである.
静注された $59 \mathrm{~F}$ は， 6 群とも時間の経過ととも 化末梢血より消失し，12 ないし 24 時間ではほとん ど消失するが，二の後再ひ次第に梢血に出現して くる．第 1，3，4 群では 12 時間でのカウント変勤 率平均値吕，各々 $-85.1 \pm 7.3 \% ，-82.0 \pm 6.4 \%$,

$-78.6 \pm 6.2 \%$ となり，全経過中最大の変動㳯を示 し，第 2 群では 24 時問でのそれがー83.3 最大の変功率を示した。つまりこの 4 群では， ${ }^{5} \mathrm{Fe}$ 静注後 12 ないし 24 時間で ${ }^{59} \mathrm{Fe}$ は末梢血よりほ之

第 1 表 S. ${ }^{69} \mathrm{Fe}$. C. 静注後の末俏血放射能の時間的变化 ( $69 \mathrm{Fe}$ count $/ 5 \mathrm{~min} / 0.02 \mathrm{cc}$ )

\begin{tabular}{|c|c|c|c|c|c|c|c|}
\hline 群 & 侍間 & $\begin{array}{c}2 \\
\text { Cカカン }\end{array}$ & 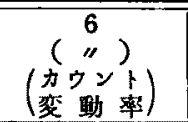 & $\left(\begin{array}{c}12 \\
\prime \prime) \\
\prime \prime\end{array}\right)$ & $\left(\begin{array}{c}24 \\
(") \\
(1)\end{array}\right)$ & $\left(\begin{array}{c}48 \\
(1) \\
(1)\end{array}\right)$ & $\left(\begin{array}{c}72 \\
(") \\
n\end{array}\right)$ \\
\hline \multirow{7}{*}{1} & 28 & 765 & $\begin{array}{r}425 \\
-44.4\end{array}$ & $\begin{array}{r}174 \\
-77.3\end{array}$ & $\begin{array}{r}161 \\
-79.0\end{array}$ & $\begin{array}{r}427 \\
-44.2\end{array}$ & $\begin{array}{r}580 \\
-24.2\end{array}$ \\
\hline & 29 & 860 & $\begin{array}{r}485 \\
-43.6\end{array}$ & $\begin{array}{r}85 \\
-90.1\end{array}$ & $\begin{array}{r}83 \\
-90.3\end{array}$ & $\begin{array}{r}424 \\
-50.7\end{array}$ & $\begin{array}{r}528 \\
-38.6\end{array}$ \\
\hline & 30 & 877 & $\begin{array}{r}329 \\
-62.5\end{array}$ & $\begin{array}{r}76 \\
-91.3\end{array}$ & $\begin{array}{r}67 \\
-92.4\end{array}$ & $\begin{array}{r}403 \\
-50.4\end{array}$ & $\begin{array}{r}670 \\
-23.6\end{array}$ \\
\hline & 69 & 829 & $\begin{array}{r}382 \\
-53.9\end{array}$ & $\begin{array}{r}180 \\
-78.2\end{array}$ & $\begin{array}{r}191 \\
-76.9\end{array}$ & $\begin{array}{r}507 \\
-38.8\end{array}$ & $\begin{array}{r}619 \\
-25.3\end{array}$ \\
\hline & 70 & 769 & $\begin{array}{r}275 \\
-64.6\end{array}$ & $\begin{array}{r}71 \\
-90.7\end{array}$ & $\begin{array}{r}201 \\
-73.8\end{array}$ & $\begin{array}{r}533 \\
-30.7\end{array}$ & $\begin{array}{r}720 \\
-6.45\end{array}$ \\
\hline & 71 & 598 & $\begin{array}{r}200 \\
-66.5\end{array}$ & $\begin{array}{r}100 \\
-3.82\end{array}$ & $\begin{array}{r}280 \\
-53.2\end{array}$ & $\begin{array}{r}500 \\
-16.3\end{array}$ & $\begin{array}{r}40 \\
-9.6\end{array}$ \\
\hline & 平 均 & & $-55.9 \pm 10.5$ & $-85.1 \div 7.3$ & $-77.6 \pm 14.8$ & $-39.1 \pm 14.6$ & $-21.2 \pm 7.6$ \\
\hline \multirow{8}{*}{2} & 34 & 738 & $\begin{array}{r}246 \\
-66.7\end{array}$ & $\begin{array}{r}13 \\
-98.2\end{array}$ & $\begin{array}{r}130 \\
-82.4\end{array}$ & $\begin{array}{r}358 \\
-51.4\end{array}$ & $\begin{array}{r}528 \\
-28.4\end{array}$ \\
\hline & 35 & 469 & $\begin{array}{r}337 \\
-28.1\end{array}$ & $\begin{array}{r}167 \\
-64.4\end{array}$ & $\begin{array}{r}119 \\
-74.6\end{array}$ & $\begin{array}{r}242 \\
-48.4\end{array}$ & $\begin{array}{r}316 \\
-32.6\end{array}$ \\
\hline & 36 & 926 & $\begin{array}{r}303 \\
-67.8\end{array}$ & $\begin{array}{r}271 \\
-70.7\end{array}$ & $\begin{array}{r}161 \\
-82.6\end{array}$ & $\begin{array}{r}283 \\
-69.4\end{array}$ & $\begin{array}{r}372 \\
-59.8\end{array}$ \\
\hline & 37 & 800 & $\begin{array}{r}241 \\
-69.9\end{array}$ & $\begin{array}{r}87 \\
-89.1\end{array}$ & $\begin{array}{r}56 \\
-93.3\end{array}$ & $\begin{array}{r}65 \\
-91.9\end{array}$ & $\begin{array}{r}295 \\
-63.1\end{array}$ \\
\hline & 38 & 1109 & $\begin{array}{r}172 \\
-84.5\end{array}$ & $\begin{array}{r}133 \\
-88.0\end{array}$ & $\begin{array}{r}220 \\
-80.1\end{array}$ & $\begin{array}{r}240 \\
-78.3\end{array}$ & $\begin{array}{r}296 \\
-73.3\end{array}$ \\
\hline & 39 & 565 & $\begin{array}{r}102 \\
-81.9\end{array}$ & $\begin{array}{r}26 \\
-95.4\end{array}$ & $\begin{array}{r}78 \\
-86.2\end{array}$ & $\begin{array}{r}124 \\
-78.1\end{array}$ & $\begin{array}{r}288 \\
-49.0\end{array}$ \\
\hline & 40 & 775 & $\begin{array}{r}396 \\
-48.9\end{array}$ & $\begin{array}{r}331 \\
-57.3\end{array}$ & $\begin{array}{r}121 \\
-84.4\end{array}$ & $\begin{array}{r}131 \\
-83.1\end{array}$ & $\begin{array}{r}251 \\
-67.6\end{array}$ \\
\hline & 平均 & & $-63.9 \pm 17.8$ & $-80.4 \pm 12.7$ & $-83.3 \pm 6.5$ & $-71.6 \pm 14.2$ & $-53.4 \pm 14.4$ \\
\hline \multirow{6}{*}{3} & 41 & 613 & $\begin{array}{r}89 \\
-85.5\end{array}$ & $\begin{array}{r}86 \\
-86.0\end{array}$ & $\begin{array}{r}65 \\
-89.4\end{array}$ & $\begin{array}{r}46 \\
-92.5\end{array}$ & $\begin{array}{r}79 \\
-87.1\end{array}$ \\
\hline & 42 & 519 & $\begin{array}{r}245 \\
-52.8\end{array}$ & $\begin{array}{r}98 \\
-79.2\end{array}$ & $\begin{array}{r}134 \\
-74.2\end{array}$ & $\begin{array}{r}145 \\
-72.1\end{array}$ & $\begin{array}{r}325 \\
-37.4\end{array}$ \\
\hline & 43 & 464 & $\begin{array}{r}200 \\
-56.9\end{array}$ & $\begin{array}{r}82 \\
82.3\end{array}$ & $\begin{array}{r}131 \\
75.3\end{array}$ & $\begin{array}{r}151 \\
67.5\end{array}$ & $\begin{array}{r}282 \\
-39.2\end{array}$ \\
\hline & 46 & 591 & $\begin{array}{r}166 \\
-71.9\end{array}$ & $\begin{array}{r}149 \\
-74.8\end{array}$ & $\begin{array}{r}143 \\
-75.8\end{array}$ & $\begin{array}{r}305 \\
-48.4\end{array}$ & $\begin{array}{r}371 \\
-37.2\end{array}$ \\
\hline & 47 & 526 & $\begin{array}{r}204 \\
-61.2\end{array}$ & $\begin{array}{r}64 \\
-87.8\end{array}$ & $\begin{array}{r}78 \\
-84.8\end{array}$ & $\begin{array}{r}224 \\
--57.4\end{array}$ & $\begin{array}{r}392 \\
-25.5\end{array}$ \\
\hline & 来均 & & $-65.7 \pm 16.1$ & $-82.0 \pm 6.4$ & $-80.0 \pm 7.4$ & $-67.6 \pm 20.4$ & $-45.3 \pm 29.4$ \\
\hline
\end{tabular}




\begin{tabular}{|c|c|c|c|c|c|c|c|}
\hline \multirow{6}{*}{4} & 50 & 1126 & $\begin{array}{r}344 \\
-69.4\end{array}$ & $\begin{array}{r}283 \\
-74.9\end{array}$ & $\begin{array}{r}502 \\
-55.4\end{array}$ & $\begin{array}{r}682 \\
-39.4\end{array}$ & $\begin{array}{r}726 \\
-35.5\end{array}$ \\
\hline & 52 & 513 & $\begin{array}{r}234 \\
--54.4\end{array}$ & $\begin{array}{r}121 \\
-76.1\end{array}$ & $\begin{array}{r}83 \\
-83.8\end{array}$ & $\begin{array}{r}155 \\
-69.8\end{array}$ & $\begin{array}{r}213 \\
-58.5\end{array}$ \\
\hline & 53 & 654 & $\begin{array}{r}280 \\
-57.2\end{array}$ & $\begin{array}{r}110 \\
-83.2\end{array}$ & $\begin{array}{r}176 \\
-73.1\end{array}$ & $\begin{array}{r}241 \\
-63.1\end{array}$ & $\begin{array}{r}310 \\
-62.6\end{array}$ \\
\hline & 55 & 817 & $\begin{array}{r}330 \\
-59.6\end{array}$ & $\begin{array}{r}114 \\
-86.0\end{array}$ & $\begin{array}{r}159 \\
-80.5\end{array}$ & $\begin{array}{r}253 \\
-69.0\end{array}$ & $\begin{array}{r}273 \\
-66.6\end{array}$ \\
\hline & 56 & 810 & $\begin{array}{r}450 \\
-44.4\end{array}$ & $\begin{array}{r}221 \\
-72.7\end{array}$ & $\begin{array}{r}255 \\
-68.5\end{array}$ & $\begin{array}{r}407 \\
-37.4\end{array}$ & $\begin{array}{r}567 \\
-30.0\end{array}$ \\
\hline & 平均 & & $-57.0 \pm 10.3$ & $-78.6 \pm 6.2$ & $-72.3 \pm 13.6$ & $-54.7 \pm 18.5$ & $-50.6 \pm 16.6$ \\
\hline \multirow{6}{*}{5} & 58 & 444 & $\begin{array}{r}214 \\
-51.8\end{array}$ & $\begin{array}{r}101 \\
-77.3\end{array}$ & $\begin{array}{r}156 \\
-64.9\end{array}$ & $\begin{array}{r}296 \\
-33.3\end{array}$ & $\begin{array}{r}319 \\
-28.1\end{array}$ \\
\hline & 59 & 636 & $\begin{array}{r}322 \\
-49,4\end{array}$ & $\begin{array}{r}116 \\
-81.8\end{array}$ & $\begin{array}{r}131 \\
-79.4\end{array}$ & $\begin{array}{r}278 \\
-56.3\end{array}$ & $\begin{array}{r}460 \\
-27.6\end{array}$ \\
\hline & 60 & 854 & $\begin{array}{r}338 \\
-60.4\end{array}$ & $\begin{array}{r}131 \\
-84.6\end{array}$ & $\begin{array}{r}266 \\
-68.9\end{array}$ & $\begin{array}{r}347 \\
-59.3\end{array}$ & $\begin{array}{r}380 \\
-55.0\end{array}$ \\
\hline & 62 & 790 & $\begin{array}{r}321 \\
-59.3\end{array}$ & $\begin{array}{r}103 \\
-86.9\end{array}$ & $\begin{array}{r}200 \\
-74.6\end{array}$ & $\begin{array}{r}251 \\
-68.2\end{array}$ & $\begin{array}{r}300 \\
-62.0\end{array}$ \\
\hline & 63 & 780 & $\begin{array}{r}340 \\
-56.4\end{array}$ & $\begin{array}{r}89 \\
-88.6\end{array}$ & $\begin{array}{r}205 \\
-73.5\end{array}$ & $\begin{array}{r}438 \\
-43.8\end{array}$ & $\begin{array}{r}461 \\
-40.9\end{array}$ \\
\hline & 平 均 & & $-55.4 \pm 6.3$ & $-83.8 \pm 6.1$ & $-72.3 \pm 6.4$ & $-52.2 \pm 16.7$ & $-42.8 \pm 19.2$ \\
\hline \multirow{6}{*}{6} & 64 & 653 & $\begin{array}{r}371 \\
-43.1\end{array}$ & $\begin{array}{r}189 \\
-71.1\end{array}$ & $\begin{array}{r}179 \\
-72.6\end{array}$ & $\begin{array}{r}312 \\
-52.2\end{array}$ & $\begin{array}{r}470 \\
-28.0\end{array}$ \\
\hline & 65 & 740 & $\begin{array}{r}302 \\
-59.2\end{array}$ & $\begin{array}{r}106 \\
-85.7\end{array}$ & $\begin{array}{r}269 \\
-63.6\end{array}$ & $\begin{array}{r}388 \\
-47.6\end{array}$ & $\begin{array}{r}565 \\
-23.6\end{array}$ \\
\hline & 66 & 483 & $\begin{array}{r}201 \\
-56.3\end{array}$ & $\begin{array}{r}144 \\
-70.2\end{array}$ & $\begin{array}{r}167 \\
-65.4\end{array}$ & $\begin{array}{r}344 \\
-28.8\end{array}$ & $\begin{array}{r}397 \\
-17.8\end{array}$ \\
\hline & 67 & 817 & $\begin{array}{r}426 \\
-47.9\end{array}$ & $\begin{array}{r}168 \\
-79.4\end{array}$ & $\begin{array}{r}156 \\
-80.9\end{array}$ & $\begin{array}{r}417 \\
-49.0\end{array}$ & $\begin{array}{r}415 \\
-49.2\end{array}$ \\
\hline & 68 & 898 & $\begin{array}{r}466 \\
-48.1\end{array}$ & $\begin{array}{r}108 \\
-88.0\end{array}$ & $\begin{array}{r}189 \\
-79.0\end{array}$ & $\begin{array}{r}448 \\
-50.1\end{array}$ & $\begin{array}{r}577 \\
-35.7\end{array}$ \\
\hline & 平 均 & & $-50.9 \pm 7.8$ & $-78.9 \pm 9.0$ & $-72.3 \div 8.9$ & $-45.5 \pm 11.2$ & $-30.9 \pm 13.5$ \\
\hline
\end{tabular}

第 1 図 S. ${ }^{69} \mathrm{Fe}$. C. 静注後未梢血放射能の時間的变化

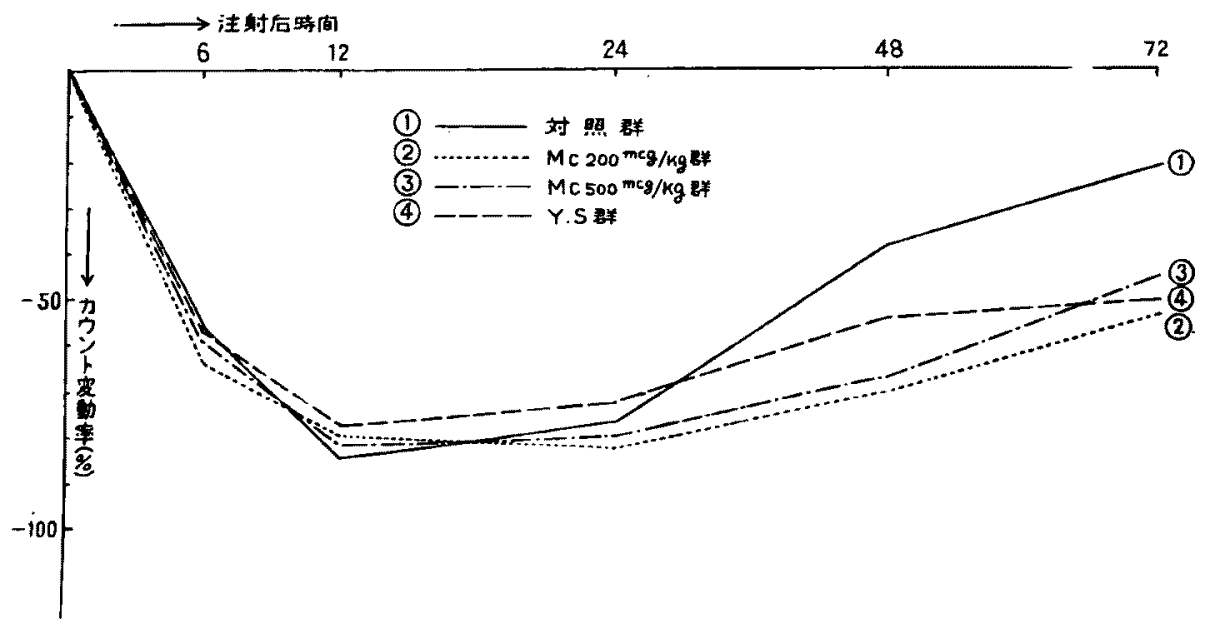


第 2 図 S. $59 \mathrm{Fe}$. C. 静往後未梢血放射能の時間的变化

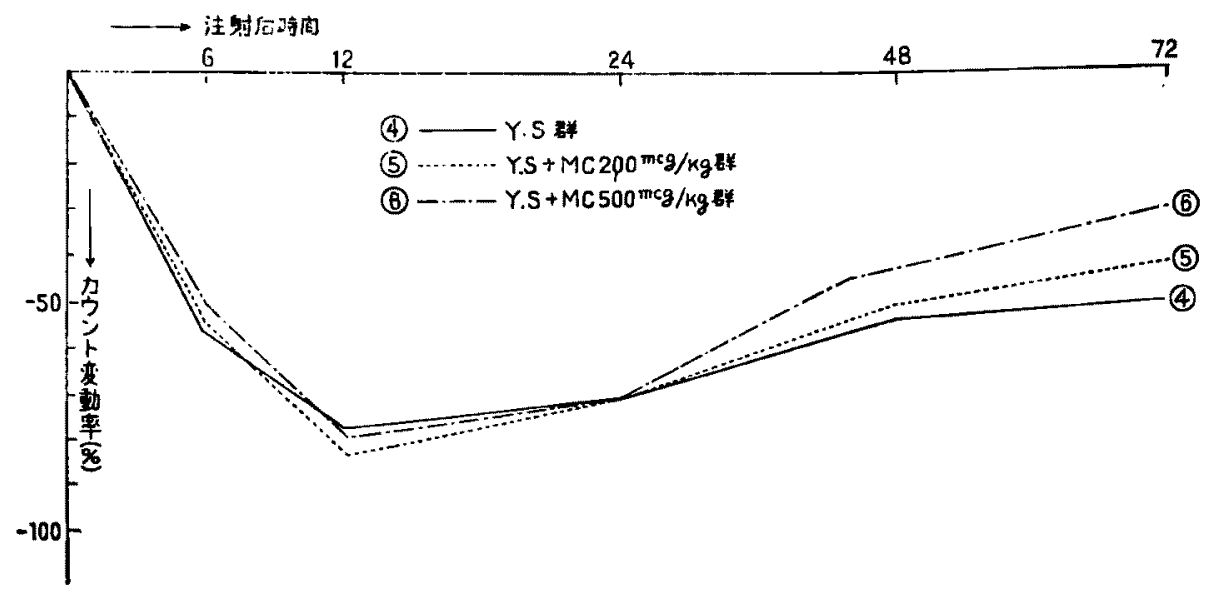

んど消失していることがかかる．72時問でのカウン 卜変動率平均值は 4 群の間化かなりの差が生じ, 対 照の第 1 群では $-21.2 \pm 7.6 \%$, 第 3 群では -45.3 $\pm 29.4 \%$ ，第 4 群では $-50.6 \pm 16.6 \%$, 第 2 群では

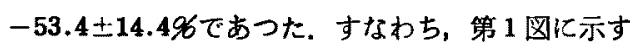

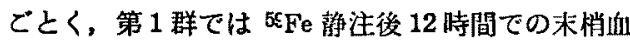
放射能の減少が，他の 3 群よりも大であり，また12 時間から 72 時間までの增加の度合も他の 3 群より も速くかつ大である。圥対し第 $2,3,4$ 群では 末梢血放射能の減少および增加の椂相は，縔やかて かつ小である.そして MC $200 \mathrm{mcg} / \mathrm{kg}$ 投与した第 2 群と $500 \mathrm{mcg} / \mathrm{kg}$ 投与した第 3 群ならびに吉田肉 腫を移植した第 4 群との間には推計学的に有意の差 がなかつた．とくに第 3 群の No. 41 と第 4 群の No. 55 とは末梢血 ${ }^{55 \mathrm{Fe}}$ の増加の度命が非常に暒れ ているのがみられた．F分布表により，てれら4群 の平均値の時間的経過の差の推計学的検定法を行 て，第 1 群と第 2，3，4 群の間とには有意の差があ るととが認められた。

つき化吉田肉腫皮下結節ラッテを $\mathrm{MC}$ で治痖し た第 $5 ， 6$ 群では，第 $2 ， 3 ， 4$ 群之落干巽なる様怕

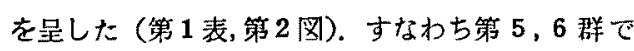
は 12 時閣までの末梢血放射能の消失する度合が， 第 4 群に校へて储かに大となり，12 時閒加ら 72 洔 閌までの增加する度へも悲やかでかつ大なり，対 照の第 1 群の变化に近似してくる傾问を示した，同 様にF分布表で筙 4 群と第 5 および第 6 群との開の 時間的経過の差の検定法を行ない，有意の差がある ことが認めら机た。なお， $\mathrm{MC} 200 \mathrm{mcg} / \mathrm{kg}$ 投与した第 5 群と $500 \mathrm{mcg} / \mathrm{kg}$ 投与した第 6 群とを比较すると，
符2図ならびに写真5，6から見てわかるように， むしろ $500 \mathrm{mcg} / \mathrm{kg}$ 投与した第 6 群の方が $\mathrm{Hb}$ の生 合成が良好であるとの結果を得た。

\section{第 2 節 血清鉄コロイト $59 \mathrm{Fe}$ 静注後72時間 の各䑏器における $59 \mathrm{Fe}$ の分布}

その成緽を示せば第 2 表に示すとおりで，各䠞器 に找ける分布率の平均值注 5 \%の危除率で求好た。

$59 \mathrm{Fe}$ 投与後 72 時間では， 6 群とも網内系のよく 発達した肝や脾への $59 \mathrm{Fe}$ incorporation が多く，肾， 骨および腫瘍へは少量，筋へは微量であつた。

1. 肝におりる $59 \mathrm{Fe}$ の平均分布率

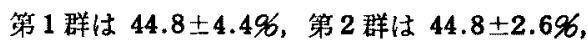
第 3 群は $38.7 \pm 6.1 \%$, 第 4 群は $48.3 \pm 4.1 \%$ ，第 5 群は $43.7 \pm 2.6 \%$, 第 6 群は $39.1 \pm 2.3 \%$ て, 第 1,2 群は大差はないか，第3群はやや減少し， 第 4 群ではやや增加し，第5.6群では第 4 群に比 して減少している。

\section{2. 脾に打ける ${ }^{59} \mathrm{Fe}$ の平均分布率}

第 1 群 $30.9 \pm 4.4 \%$ ，第 2 群 $39.9 \pm 3.9 \%$ ，第 3 群 $47.5 \pm 7.2 \%$ ，第 4 群 $29.6 \pm 4.5 \%$ ，第 5 群 26.3 土4.4\%，第 6 群 $22.3 \pm 2.8 \%$ であつて，第 $2 \cdot 3$ 群は笨 1 群より李增加しているが，第 4・5・6 群で は減少し䈀1碓よりも低い分有率を示した。

\section{3. 行における $59 \mathrm{Fe}$ の平均分布摔}

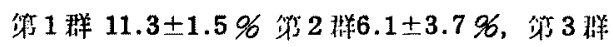
$5.3 \pm 1.8 \%$ ，第 4 磁 $8.9 \pm 1.5 \%$ ，第 5 群 $9.0 \pm 1.3$

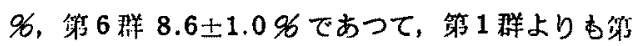
$2 \cdot 3$ 群は減少し, 第4・5・6 群では差はないが, 第 1 群よりあ少なく䇲 $2 \cdot 3$ 群よりもやや多かつた。 4. 骨に拈ける $59 \mathrm{Fe}$ の平均分布率 
制癌剂の担癌体に及沽す影帮飞関する研究

第 2 表 S. ${ }^{69} \mathrm{Fe}$. C. 靜注後72時間の各践器における分布 $\left({ }^{69} \mathrm{Fe}\right.$ count $\left./ 1 \mathrm{~min} / \mathrm{g}\right)$

\begin{tabular}{|c|c|c|c|c|c|c|c|}
\hline 群 & 番号 & 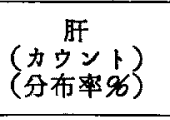 & $\left(\begin{array}{l}\text { 脾 } \\
\prime \prime\end{array}\right)$ & $\left(\begin{array}{l}\quad \\
\prime \prime\end{array}\right)$ & $\left(\begin{array}{l}\text { 骨 } \\
" \prime\end{array}\right)$ & $\left\{\begin{array}{c}\text { 筋 } \\
\prime \prime \\
\prime \prime\end{array}\right)$ & $\begin{array}{l}\text { ("腫 } \\
(" \text { 瘦 }\end{array}$ \\
\hline \multirow{7}{*}{1} & 28 & $\begin{array}{r}88910 \\
46.8\end{array}$ & $\begin{array}{r}61412 \\
32.3\end{array}$ & $\begin{array}{l}21173 \\
11.12\end{array}$ & $\begin{array}{r}13615 \\
7.2\end{array}$ & $\begin{array}{r}5090 \\
2.6\end{array}$ & \\
\hline & 29 & $\begin{array}{r}82315 \\
39.6\end{array}$ & $\begin{array}{r}64930 \\
31.3\end{array}$ & $\begin{array}{r}27897 \\
13.4\end{array}$ & $\begin{array}{r}27620 \\
13.2\end{array}$ & $\begin{array}{r}5186 \\
2.5\end{array}$ & \\
\hline & 30 & $\begin{array}{r}88726 \\
45.8\end{array}$ & $\begin{array}{r}59430 \\
30.6\end{array}$ & $\begin{array}{r}20415 \\
10.5\end{array}$ & $\begin{array}{r}20635 \\
10.7\end{array}$ & $\begin{array}{r}4468 \\
2.4\end{array}$ & \\
\hline & 69 & $\begin{array}{r}89470 \\
40.6\end{array}$ & $\begin{array}{r}81973 \\
37.2\end{array}$ & $\begin{array}{r}23802 \\
10.8\end{array}$ & $\begin{array}{r}20833 \\
9.5\end{array}$ & $\begin{array}{r}4063 \\
1.9\end{array}$ & \\
\hline & 70 & $\begin{array}{r}88952 \\
50.9\end{array}$ & $\begin{array}{r}42264 \\
24.2\end{array}$ & $\begin{array}{r}21450 \\
12.3\end{array}$ & $\begin{array}{r}18365 \\
10.5\end{array}$ & $\begin{array}{r}3724 \\
2.1\end{array}$ & \\
\hline & 71 & $\begin{array}{r}64539 \\
44.9\end{array}$ & $\begin{array}{r}42286 \\
29.5\end{array}$ & $\begin{array}{r}13820 \\
9.6\end{array}$ & $\begin{array}{r}15320 \\
10.7\end{array}$ & $\begin{array}{r}7604 \\
5.3\end{array}$ & \\
\hline & 平均 & $44.8 \pm 4.4$ & $30.9 \pm 4.4$ & $11.3 \pm 1.5$ & $10.3 \pm 2.0$ & $2.8 \pm 1.3$ & \\
\hline \multirow{8}{*}{2} & 34 & $\begin{array}{r}110471 \\
43.4\end{array}$ & $\begin{array}{r}107220 \\
42.1\end{array}$ & $\begin{array}{r}14870 \\
5.8\end{array}$ & $\begin{array}{r}19315 \\
7.6\end{array}$ & $\begin{array}{r}2905 \\
1.1\end{array}$ & \\
\hline & 35 & $\begin{array}{r}85143 \\
45.2\end{array}$ & $\begin{array}{r}71615 \\
38.1\end{array}$ & $\begin{array}{r}12008 \\
6.4\end{array}$ & $\begin{array}{r}14151 \\
7.5\end{array}$ & $\begin{array}{r}5365 \\
2.8\end{array}$ & \\
\hline & 36 & $\begin{array}{r}111373 \\
49.3\end{array}$ & $\begin{array}{r}77486 \\
34.3\end{array}$ & $\begin{array}{r}15521 \\
6.9\end{array}$ & $\begin{array}{r}18360 \\
8.1\end{array}$ & $\begin{array}{r}3085 \\
1.4\end{array}$ & \\
\hline & 37 & $\begin{array}{r}131285 \\
42.8\end{array}$ & $\begin{array}{r}131755 \\
43.0\end{array}$ & $\begin{array}{r}17617 \\
5.8\end{array}$ & $\begin{array}{r}22701 \\
7.4\end{array}$ & $\begin{array}{r}2764 \\
1.0\end{array}$ & \\
\hline & 38 & $\begin{array}{r}139715 \\
42.7\end{array}$ & $\begin{array}{r}139375 \\
42.6\end{array}$ & $\begin{array}{r}17522 \\
5.4\end{array}$ & $\begin{array}{r}28740 \\
8.7\end{array}$ & $\begin{array}{r}1718 \\
0.6\end{array}$ & \\
\hline & 39 & $\begin{array}{r}120857 \\
42.1\end{array}$ & $\begin{array}{r}122740 \\
42.7\end{array}$ & $\begin{array}{r}16296 \\
5.7\end{array}$ & $\begin{array}{r}24182 \\
8.4\end{array}$ & $\begin{array}{r}3069 \\
1.1\end{array}$ & \\
\hline & 40 & $\begin{array}{r}119796 \\
48.1 \\
\end{array}$ & $\begin{array}{r}91851 \\
36.8 \\
\end{array}$ & $\begin{array}{r}16296 \\
6.5 \\
\end{array}$ & $\begin{array}{r}19503 \\
7.8 \\
\end{array}$ & $\begin{array}{r}1945 \\
0.8 \\
\end{array}$ & \\
\hline & 平均 & $44.8 \pm 2.6$ & $39.9 \pm 3.9$ & $6.1 \pm 0.3$ & $7.9 \pm 0.8$ & $1.3 \pm 0.6$ & \\
\hline \multirow{6}{*}{3} & 41 & $\begin{array}{r}101546 \\
36.0\end{array}$ & $\begin{array}{r}147360 \\
52.2\end{array}$ & $\begin{array}{r}12470 \\
4.4\end{array}$ & $\begin{array}{r}18322 \\
6.5\end{array}$ & $\begin{array}{r}2571 \\
0.9\end{array}$ & \\
\hline & 42 & $\begin{array}{r}106063 \\
33.5\end{array}$ & $\begin{array}{r}169150 \\
53.3\end{array}$ & $\begin{array}{r}14394 \\
4.5\end{array}$ & $\begin{array}{r}25053 \\
7.9\end{array}$ & $\begin{array}{r}2587 \\
0.8\end{array}$ & \\
\hline & 43 & $\begin{array}{r}94868 \\
43.6\end{array}$ & $\begin{array}{r}83905 \\
38.6\end{array}$ & $\begin{array}{r}12871 \\
5.9\end{array}$ & $\begin{array}{r}22070 \\
10.2\end{array}$ & $\begin{array}{r}3737 \\
1.7\end{array}$ & \\
\hline & 46 & $\begin{array}{r}84390 \\
\mathbf{4 5 . 4}\end{array}$ & $\begin{array}{r}80261 \\
43.2\end{array}$ & $\begin{array}{r}11405 \\
6.1\end{array}$ & $\begin{array}{r}5907 \\
3.2\end{array}$ & $\begin{array}{r}3918 \\
3.1\end{array}$ & \\
\hline & 47 & $\begin{array}{r}57299 \\
35.1 \\
\end{array}$ & $\begin{array}{r}81585 \\
50.0 \\
\end{array}$ & $\begin{array}{r}9233 \\
5.7 \\
\end{array}$ & $\begin{array}{r}14043 \\
8.6 \\
\end{array}$ & $\begin{array}{l}965 \\
0.6 \\
\end{array}$ & \\
\hline & 平均 & $38.7 \pm 6.1$ & $47.5 \pm 7.2$ & $5.3 \pm 1.8$ & $7.3 \pm 3.0$ & $1.2 \pm 0.7$ & \\
\hline \multirow{6}{*}{4} & 50 & $\begin{array}{r}79928 \\
\mathbf{5 3 . 3}\end{array}$ & $\begin{array}{r}34989 \\
23.3\end{array}$ & $\begin{array}{r}15962 \\
10.6\end{array}$ & $\begin{array}{r}8842 \\
5.9\end{array}$ & $\begin{array}{r}4012 \\
2.7\end{array}$ & $\begin{array}{r}6360 \\
4.2\end{array}$ \\
\hline & 52 & $\begin{array}{r}65524 \\
46.7\end{array}$ & $\begin{array}{r}41727 \\
31.7\end{array}$ & $\begin{array}{r}9040 \\
6.9\end{array}$ & $\begin{array}{r}7675 \\
5.8\end{array}$ & $\begin{array}{r}1451 \\
1.1\end{array}$ & $\begin{array}{r}6352 \\
4.8\end{array}$ \\
\hline & 53 & $\begin{array}{r}72203 \\
46.6\end{array}$ & $\begin{array}{r}43854 \\
28.3\end{array}$ & $\begin{array}{r}14793 \\
9.6\end{array}$ & $\begin{array}{r}13435 \\
8.7\end{array}$ & $\begin{array}{r}3545 \\
2.3\end{array}$ & $\begin{array}{r}6978 \\
4.5\end{array}$ \\
\hline & 55 & $\begin{array}{r}100348 \\
42.8\end{array}$ & $\begin{array}{r}82700 \\
35.3\end{array}$ & $\begin{array}{l}2136 \\
29.1\end{array}$ & $\begin{array}{r}14390 \\
6.1\end{array}$ & $\begin{array}{r}6966 \\
3.0\end{array}$ & $\begin{array}{r}8725 \\
3.7\end{array}$ \\
\hline & 56 & $\begin{array}{r}109485 \\
49.1 \\
\end{array}$ & $\begin{array}{r}65439 \\
29.3\end{array}$ & $\begin{array}{r}17986 \\
8.1\end{array}$ & $\begin{array}{r}14295 \\
6.4\end{array}$ & $\begin{array}{r}8472 \\
3.8\end{array}$ & $\begin{array}{r}3.7 \\
7359 \\
3.3 \\
\end{array}$ \\
\hline & 平均 & $48.3 \pm 4.1$ & $29.6 \pm 4.5$ & $8.9 \pm 1.5$ & $6.6 \pm 1.3$ & $2.6 \pm 1.0$ & $4.1 \pm 0.6$ \\
\hline
\end{tabular}




\begin{tabular}{|c|c|c|c|c|c|c|c|}
\hline \multirow{6}{*}{5} & 58 & $\begin{array}{r}81882 \\
44.5\end{array}$ & $\begin{array}{r}36576 \\
19.9\end{array}$ & $\begin{array}{r}19902 \\
10.8\end{array}$ & $\begin{array}{r}20356 \\
11.1\end{array}$ & $\begin{array}{r}3298 \\
1.8\end{array}$ & $\begin{array}{r}21904 \\
11.9\end{array}$ \\
\hline & 59 & $\begin{array}{r}86575 \\
43.3\end{array}$ & $\begin{array}{r}60516 \\
30.3\end{array}$ & $\begin{array}{r}17913 \\
9.0\end{array}$ & $\begin{array}{r}17857 \\
8.9\end{array}$ & $\begin{array}{r}4344 \\
2.2\end{array}$ & $\begin{array}{r}12659 \\
6.3\end{array}$ \\
\hline & 60 & $\begin{array}{r}119335 \\
47.6\end{array}$ & $\begin{array}{r}62331 \\
24.9\end{array}$ & $\begin{array}{r}18922 \\
7.5\end{array}$ & $\begin{array}{r}21546 \\
8.6\end{array}$ & $\begin{array}{r}6966 \\
2.8\end{array}$ & $\begin{array}{r}21631 \\
8.6\end{array}$ \\
\hline & 62 & $\begin{array}{r}85963 \\
42.2\end{array}$ & $\begin{array}{r}j 9421 \\
29.2\end{array}$ & $\begin{array}{r}16400 \\
8.1\end{array}$ & $\begin{array}{r}20034 \\
9.8\end{array}$ & $\begin{array}{r}5921 \\
2.9\end{array}$ & $\begin{array}{r}15864 \\
7.8\end{array}$ \\
\hline & 63 & $\begin{array}{r}86432 \\
41.1\end{array}$ & $\begin{array}{r}57635 \\
27.4\end{array}$ & $\begin{array}{r}19967 \\
9.5\end{array}$ & $\begin{array}{r}21488 \\
10.2\end{array}$ & $\begin{array}{r}4631 \\
2.2\end{array}$ & $\begin{array}{r}20054 \\
9.6\end{array}$ \\
\hline & 平均 & $43.7 \pm 2.6$ & $26.3 \pm 4.4$ & $9.0 \pm 1.3$ & $9.7 \pm 1.1$ & $2.4 \pm 0.5$ & $8.8 \pm 2.2$ \\
\hline \multirow{6}{*}{6} & 64 & $\begin{array}{r}83263 \\
42.0\end{array}$ & $\begin{array}{r}43937 \\
22.1\end{array}$ & $\begin{array}{r}19068 \\
9.6\end{array}$ & $\begin{array}{r}22683 \\
11.4\end{array}$ & $\begin{array}{r}2091 \\
1.1\end{array}$ & $\begin{array}{r}27340 \\
13.8\end{array}$ \\
\hline & 65 & $\begin{array}{r}76718 \\
37.4\end{array}$ & $\begin{array}{r}47569 \\
23.2\end{array}$ & $\begin{array}{r}19769 \\
9.7\end{array}$ & $\begin{array}{r}19505 \\
9.5\end{array}$ & $\begin{array}{r}2486 \\
1.2\end{array}$ & $\begin{array}{r}38940 \\
19.0\end{array}$ \\
\hline & 66 & $\begin{array}{r}83318 \\
38.8\end{array}$ & $\begin{array}{r}56157 \\
26.2\end{array}$ & $\begin{array}{r}17385 \\
8.1\end{array}$ & $\begin{array}{r}25763 \\
12.0\end{array}$ & $\begin{array}{r}3373 \\
1.6\end{array}$ & $\begin{array}{r}28560 \\
13.3\end{array}$ \\
\hline & 67 & $\begin{array}{r}88682 \\
40.7\end{array}$ & $\begin{array}{r}41116 \\
18.9\end{array}$ & $\begin{array}{r}16360 \\
7.5\end{array}$ & $\begin{array}{r}24870 \\
11.4\end{array}$ & $\begin{array}{r}2452 \\
1.1\end{array}$ & $\begin{array}{r}44400 \\
20.4\end{array}$ \\
\hline & 68 & $\begin{array}{r}79561 \\
36.7\end{array}$ & $\begin{array}{r}46319 \\
21.3\end{array}$ & $\begin{array}{r}17440 \\
8.0\end{array}$ & $\begin{array}{r}21343 \\
9.9\end{array}$ & $\begin{array}{r}2117 \\
1.0\end{array}$ & $\begin{array}{r}50213 \\
23.1\end{array}$ \\
\hline & 平均 & $39.1 \pm 2.3$ & $22.3 \pm 2.8$ & $8.6 \div 1.0$ & $10.8 \pm 1.1$ & $1.2 \pm 0.3$ & $17.9 \pm 4.6$ \\
\hline
\end{tabular}

第 1 群 $10.3 \pm 2.0 \%$ ，第 2 群 $7.9 \pm 0.8 \%$ ，第 3 群 $7.3 \pm 3.09 \%$ ，第 4 群 $6.6 \pm 1.3 \%$ ，第 5 群 $9.7 \pm$ 1.196 ，第 6 群 $10.8 \pm 1.196$ であつた，第 $2 \cdot 3$ 群で は第 1 群より減少し，第 4 群では 6 群中最低分布率 となり，第 5 - 6 群では再び増加していた。

5. 筋における $59 \mathrm{Fe}$ の平均分布萃

第 1 群 2.8土1.3\%，第 2 群 $1.3 \pm 0.6 \%$ ，第 3 群 $1.2 \pm 0.7 \%$ ，第 4 群 $2.6 \pm 1.0 \%$ ，第 5 群 $2.4 \pm 0.5$ \%、第 6 群 $1.2 \pm 0.396$ で， 6 群の閪にははよ。よ゙ 差はみられなかつた。

6. 第 4.5.6群における腫瘤の平均分布伡

第 4 群 $4.1 \pm 0.6 \%$, 第 5 群 8.8 $2.2 \%$, 第 6 群 $17.9 \pm 4.696$ であつて，第 4 群より第 5 群は增加し、 第 6 群では更に增加していた。

\section{第 3 節血清鉄コロイド59Fe輅注後72時間の 肝非へミン鉄}

肝の韭へミン鉄を総非へミン鉄としてその放射能 を测定したものを H としさらに Ferritin 分剧のみ について测つたものを $\mathrm{F}$ として，その百分本を F/H 自で表わし, 各群の百分率の平均值を5\%の 危険率で求めたととろ，第 3 表のどとき結果を得た。 第 1 群 $42.4 \pm 4.5 \%$, 第 2 群 $38.6 \pm 16.5 \%$ ，第 3


$\pm 3.49 \%$ ，第 6 群 41.7 5.9\%であつた。すなわち 正常ラッテに MC を投与した第 $2 \cdot 3$ 群では対照の
第 1 群より も百分率汃低下し，第 4 群すなすち担癌 ラッテす同様に対照群より低下している. しかし担 癌ラッテを MC て治療すると, 百分率は増加し， 対照群に近ずいてくる，つまり正常ラッテに MC を投与したり担湆状態のラッテでは，対照の正常ラ 第 3 表 S. 59 Fe. C. 静注後72時間の肝非へミン鉄 ( $59 \mathrm{Fe}$ count $/ 1 \mathrm{~min} / 0.5 \mathrm{~g}$ )

\begin{tabular}{|c|c|c|c|c|}
\hline 群 & 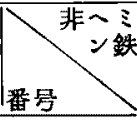 & 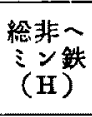 & $\begin{array}{l}\text { フェ } \\
x^{\prime} \\
(\mathrm{F})\end{array}$ & $\mathrm{F} / \mathrm{H} \times 100(\mathscr{6})$ \\
\hline \multirow{7}{*}{1} & 28 & 37989 & 17275 & 45.5 \\
\hline & 29 & 25640 & 10282 & 40.1 \\
\hline & 30 & 28981 & 14059 & 48.5 \\
\hline & 69 & 24075 & 10083 & 41.9 \\
\hline & 70 & 18963 & 7206 & 38.0 \\
\hline & 71 & 12022 & 4877 & 40.6 \\
\hline & 平均 & & & $42.4 \pm 4.5$ \\
\hline \multirow{8}{*}{2} & 34 & 25871 & 11225 & 43.3 \\
\hline & 35 & 20597 & 8107 & 39.3 \\
\hline & 36 & 21059 & 9477 & 45.0 \\
\hline & 37 & 28819 & 10516 & 36.5 \\
\hline & 38 & 32512 & 12355 & 38.0 \\
\hline & 39 & 18913 & 6280 & 33.2 \\
\hline & 40 & 18606 & 6591 & 35.4 \\
\hline & 平均 & & & $38.6 \pm 16.5$ \\
\hline
\end{tabular}




\begin{tabular}{|c|c|c|c|c|}
\hline \multirow{6}{*}{3} & 41 & 32199 & 10031 & 32.1 \\
\hline & 42 & 34233 & 12449 & 36.3 \\
\hline & 43 & 30103 & 11278 & 39.5 \\
\hline & 46 & 24441 & 8395 & 34.3 \\
\hline & 47 & 24653 & 8560 & 34.7 \\
\hline & 平均 & & & $35.4 \pm 3.4$ \\
\hline \multirow{6}{*}{4} & 50 & 13660 & 5945 & 33.7 \\
\hline & 52 & 13146 & 4502 & 34.2 \\
\hline & 53 & 14173 & 6130 & 43.2 \\
\hline & 55 & 24593 & 7738 & 31.5 \\
\hline & 56 & 20169 & 8068 & 40.0 \\
\hline & 平 均 & & & $36.5 \pm 6.2$ \\
\hline \multirow{6}{*}{5} & 58 & 26781 & 12030 & 44.9 \\
\hline & 59 & 28672 & 12510 & 43.6 \\
\hline & 60 & 21564 & 8647 & 40.1 \\
\hline & 62 & 19981 & 7892 & 39.5 \\
\hline & 63 & 20512 & 8307 & 40.5 \\
\hline & 平拘 & & & $41.7 \pm 3.4$ \\
\hline \multirow{6}{*}{6} & 64 & 21060 & 8326 & 39.5 \\
\hline & 65 & 15829 & 7654 & 48.3 \\
\hline & 66 & 18631 & 6558 & 35.2 \\
\hline & 67 & 21636 & 9128 & 42.2 \\
\hline & 68 & 17806 & 7714 & 43.3 \\
\hline & 均 & & & $41.7 \pm 5.9$ \\
\hline
\end{tabular}

ッテよりも肝膆鉄の中の Ferritin の相対比率が低 下し、Hemosiderin が肝汇抑留されるが，担癌ラッ テを MC で治療すると再び Ferritin の相対比率が 增加してくることが示された。なお Spot Paper Autoradiograph で Hb 合成荤延のみられた No. 41, No. 55, No. 62 はいずれもその群の平均值上りも低 い百分率を示している.

\section{第 4 節 腫演の発育}

第 4·5・6 群の腫澔直経（縦・蓝の直径の和 $\times \frac{1}{2}$ ） の経日的平均を図示すると，第 $3 \cdot 4 \cdot 5$ 図のことく である，すはわち笨 4 群では全例とも，日ととも 腫場は薪しく增大し，その中であ Spot Paper Autoradiograph で Hb 合成遅延のみられた No. 55 は移 植 12 日目にはこの群の 5 匹中最大の腫瑝直径を示

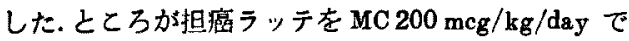
治瘵した第 5 群では MC 投与 $3 \sim 4$ 日目に腫场の 增大が抑えられ発育を一時停止し，MC 投与䊏了翌 日には腫場はむしろ縮小するが，その後再び增大し た. なお Spot Paper Autoradiograph で Hb 合成掘
第 3 図 第 4 珒の腫場直徍の経日的変化

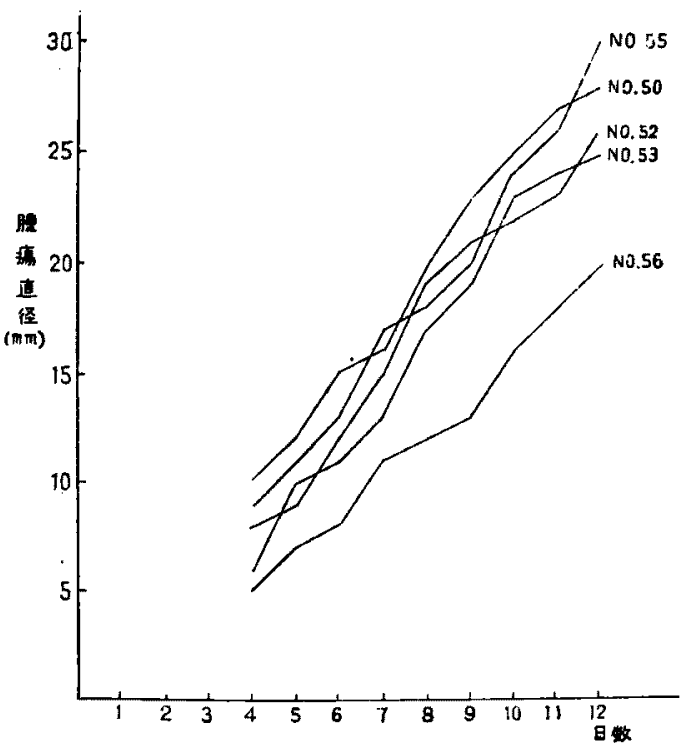

第 4 圆 第 5 群の厘第直经の経日的変化

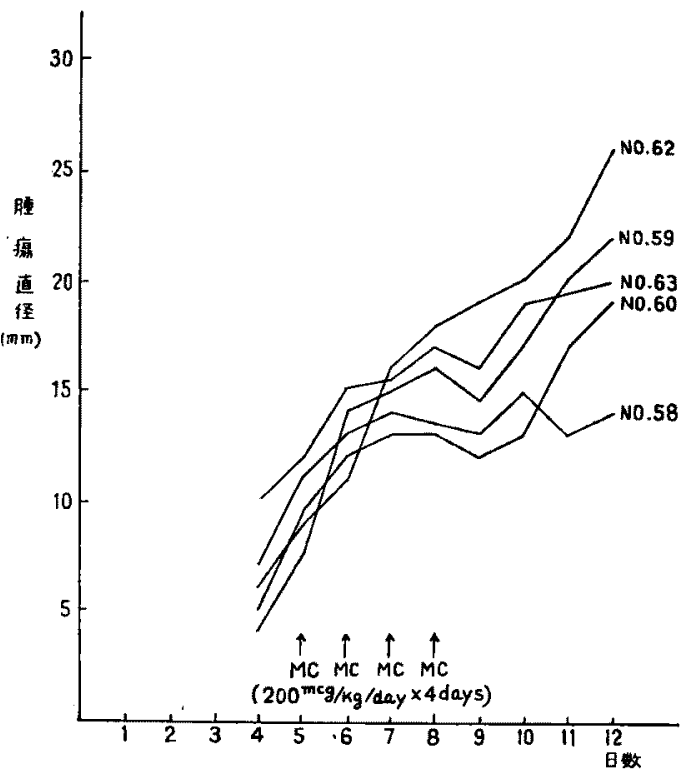

延のみられた No.62 は MC を投与したにあ拘らず， 腄㻤は日とともに增大し移楠12日目には 5 匹中最大 の隀瘍直径を示した。しかるに MC $500 \mathrm{mcg} / \mathrm{kg} / \mathrm{day}$ で治療した第 6 群では MC 投与3日目より腫演は 次第に縮小しはじめ，ほぼ治㽷開始前日の大さにま で恢䛃した。

すなわち MC $200 \mathrm{mcg} / \mathrm{kg} / \mathrm{day} 4$ 日連続投与群で は腫瘍を完全に治源縮小せしめるととはできなかつ 
第 5 区 第 6 群の腫瘦直径の経日的変化

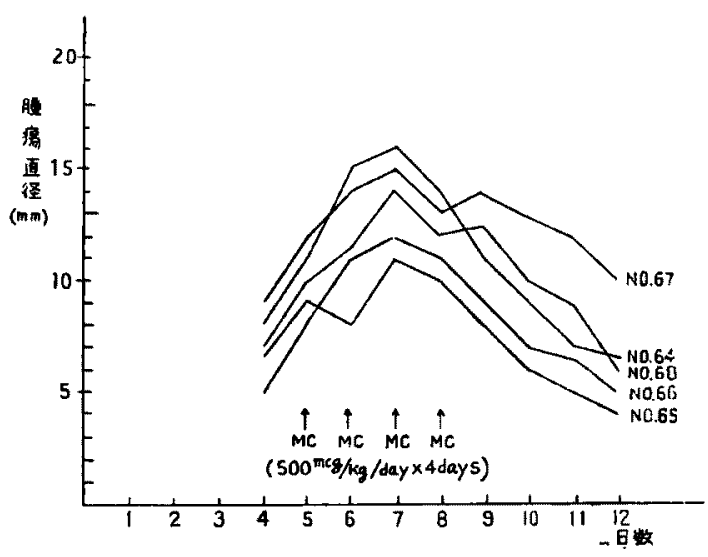

たが，MC $500 \mathrm{mcg} / \mathrm{kg} / \mathrm{day} 4$ 日連続投与群では腫煌 は一時増大するが，その後は日ととあに縮少し治凂 する㑯向が認められた，要するに, $200 \mathrm{mcg} / \mathrm{kg} / \mathrm{day}$ で治療した群の腫湯組織所見では MC か腫湯に制 癌的に有効であつたと認められるあのはなかつたが， $500 \mathrm{mcg} / \mathrm{kg} / \mathrm{day}$ で治療した群の腫瘍は写真 7，8の ごとく結合織により周囲と明らかに demarkierenさ れ，腫湯細胞む著明に破罗され凬瘍の中心は壊死に おち入り治瘷への過程が証明された。なお特有なと とは, Demarkationszone には Hemosiderin の沈着 が著明にみられることである（写真 9 ).

\section{第4章 総括ならひに考按}

われわれが臨床上，使用している制㾔郕の投与は かなり大量で，加衝撃的であり，MCは術前 1 日 $10 \mathrm{mg} 4$ 日連続投与という皘極的方法である。この 量は本実験のラッテ当り $200 \mathrm{mcg} / \mathrm{kg} /$ day 投与量に 相当するか，これは本実験での吉田肉腫の治應量に は及ばず，したがつて $500 \mathrm{mcg} / \mathrm{kg} / \mathrm{day}$ 投与群を設 けて観察した，動物実験であ制癌剂の莱用量，投与 形式はその制癌能を大きく左右するものである。こ のような見地から，わたくしは健康な正常㲜物化制 癌剂を投与したり，動物を担癌状態にしたり，さら に担癌怔物に制癌郕を投与したりしてみて，これら の場合，網内系機能はどのように変化するかを血清 鉄コロイド $59 \mathrm{Fe}$ を用いて，鉄の会喰及び合成能と いう新しい観点から実験を行なつた。いまその成縝 をとこに総括し考按してみることにする．妹尾(7) は鉄代謝における絧内系の役割について，羂汁，エ バンス青，大腸菌その他を反復注射してあらかじめ 絧内系を阻害した家鬼に，鉄コロイドを注入し同コ
ロイドの血清からの消失，細内系貪喰像，鉄のへ モグロビン，フーリチンなどへの移行を䉓顥的に 観察したところ，網内系細胞のコロイド食喰能は かなりよく保たされているにも拘らず，令喰後の 鉄処理機能は会喰能之関係なく阴管されるとのへ ている，乙の研㠰は網内系細胞機能の实体を正し く理解する上にも，また絸内系機能検査としての 価値からみても，非常に畘味あり重要なことであ る18)。生休に投与されたコロイド状の鉄は，まず 朋などの絧内系にとられ，ついで鉄は遊離して血

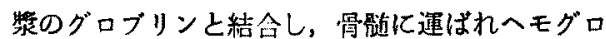
ビン合成に用いられるものと考えられる。

一方網内系機能之腫湟の增殖については多くの

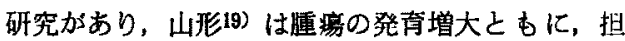
凬場患者の網内系機能が低下することを, AdlerReimann 法で認め，志村20）は網内系機能立進処置

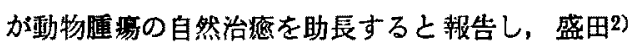
は網内系細胞の一機能産物としての非特異性抗体た る催喰菌作用性物犋すなわちオプソニンの血中增減

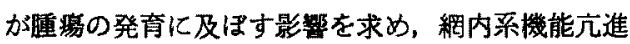
状態では一抗体のみの産生が促進されるのではなく その他の抗体産生も促進されるものであり，それら の抗体の中に抗腫場性のものがないとは断言できな いとのへ，また久留21)は人血清内に Ehrlich 腹水癌 細胞溶解能があり，溶解にあずかる血清中の析热因 子は、タ-グロブリン分㓶に関保があるとして補体に 属するあのとの見解をとつており，Pillemer22) らは 血中の易熱性蛋白質 Properdin を発見し，乙れが 一般細菌感染防徐力の主体をなすすので，しかす腫 掦の進展に従い血中 Properdin は減少することを 認めている，教室の折田23) は正常動物に制癌剂を 投与した場合には Properdin は一時的に低下し， また癌を移植した場合にす低下するが，担癌マウス に制癌剂をもちいた場合には Properdin は次第に 增加してくると報告している，盛田2)，近藤3)，今 永 4 ，津久井5) らは正常動物ないし担癌動物汇制癌 剂を投与すれば，制癌効果よりるかえつて動物の全 身抵抗力を低下さし増演作用のあることを報告して いるが，私の上述の実験結果でも，正常ラッテに MC を投与した第 2,3 群および担癌状態である第 4 群では, 網内系機能は対照群に比べて低下してお り，諸家の報告と一致しており，また MC の量を 增すにつれて $\mathrm{Hb}$ 合成の逮延が起るととが示され た，静注された血清鉄コロイド日e の末梢血にお 
ける放射能の初期隇少は $59 \mathrm{Fe}$ が網内系に會飧され る過程を示し，それに続く增加はこの後をこて Ferritin や Hemosiderin に生合成されていく過程 を示すすので，維内系のコロイド頜险能と非へミン 鉄合成機能とを表現しているすのと考えられる、す なわち私の実験では MC を投与した正常ラッテや 担癌ラッテでは，絧内系がブロックされ鉄代謝が障 碍されるけれども，担癌ラッテに MC を投与した第 5,6 群では，一旦低下した網内系機能がむしろ改 善され，正常に近ずく傾向のあることが認められた。

つぎに担痹動物を MC で治療した第 5 群と第 6 群とにおける隀瘍の発育の様相についてみるに，第 5 群では皮下腫瑒が一時縮小する傾向があるけれど あ, その後再び増大していくということは, MC $200 \mathrm{mcg} / \mathrm{kg} / \mathrm{dag} \times 4$ 日の投与量では，一㭙腫演の 縮小を来して，その結果絧内系機能の一時的改善に よる制癌效果はあても，結局は腫湯の発南力が生体 の抗腫浧力より大であつたためか，あるいはその後 引きつづき投与された制癌剂が生体の抗畽湶力を減

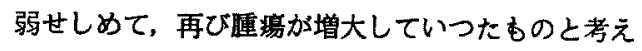
られる.しかるに MC $500 \mathrm{mcg} / \mathrm{kg} / \mathrm{day} \times 4$ 日投与 した第 6 群では第 5 群よりあ疅堨発育抑制力が大で あつたために一層網内系機能が改善されて, 治療に 䖯くという結果がえられたものと考えられ，この理 由から短期に大量の制㿋剂を投与するのが良いのて はないかと考えられる。

さらら有賀24)は悪性瘇瘍の鉄代謝の研究の中で， 担癌マウスの ${ }^{69 \mathrm{Fe}}$ の動物分布について次のでとく 報じている，吸収後の ${ }^{59} \mathrm{Fe} の$ 組織単位重量当りの 分布率はまず肝，脾に多く，10日後より次第に減ず

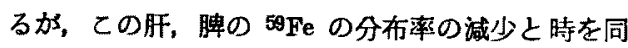
じくして, 隀湯の ${ }^{59} \mathrm{Fe}$ 分布率の増加が始まり，乙く に肝の ${ }^{5 \mathrm{Fe}}$ 分布率の減少に呼応するかのように,

腫場のそれが增加するのがみられ，この機序につい ては，生体の政プールである肝から鉄が放出されて 腄場に移行した結果であろうと考え，しかすこの腫 場 $\mathrm{E}^{\mathrm{F} e}$ の増加は，米山・緗野法16) による $\mathrm{P}_{1} お よ$ び $P_{I I I}$ 分画の 59Fe 増加が主体であるとのべている. 佐藤25) は強度の會血を伴なう多くの腫第疾患では， かなりの量の鉄・銅が肝・脾に蓄積され，鉄・銅 の利用障显を来たし，ひいては $\mathrm{Hb} や$ catalase $の$ 減少を惹起すると報し，Price \& Greenfield26), Greenstein ${ }^{27}$ ) は担瘦生体では鉄か腫場組䄳に蓄皘さ れ，その結果肝 catalase 乙 Hbの久乏が惹起され るといつている, 生体における鉄は Hb, catalase, cytochrome $\mathrm{C}$ など重要呵吸倩菜の核をなしており， さらに Ferritin, Hemosiderin, Transferritin など 一連の鉄蛋白体の発見によつててれら醉素と脿器眝 娍鉄との関連屯濑次明らかにせられつつある。例え ば蔵器鉄の中で metabolic activ とみられる Ferritin は catalase の前段陆と考えら扎る. Greenstein27) は, 担癌生体において睡缹を外科的に除去主ること によつて, catalase や血清鉄および血色素が正常に 復㷌する事実を示しているが、これは癌組織が Toxohormon を産出している有力な社左であり， 腫㻛は Toxohormon を除外して論じ得ないと同様 に, 鉄代謝も Toxohormon との関連を無視しては 論じえない，飯島ひ)らは Toxohormon はマウス の肝 Ferritin 鉄を減ずると報じ，また胃癌患者 において肝カタラーゼの活性度の低下と同時に Ferritin 分剖鉄の減少，核酸分劃の增加を相刘的に 証明している.

さて私の実験において，対厝群では各臟器の $59 \mathrm{Fe}$ は72時間で訮・脾に最も多く眝留されて眝腀鉄と して存し，婜・骨には中等量，筋には微量であつた。 しかし正常ラッテに MC を投与した第 2 およひ第 3群では，骨への incorporation がやや減少し， その代り脾への incorporation が增加し，肝では Hemosiderin の抑留が起こり活性鉄である Ferritin の減少を来たし，ひいては $\mathrm{Hb}$ 合成能も低下した。 このととは MC を正常動物に投与すると, 網内系 の全機能が低下し，ひいて高髄機能も低下してい るので，的）は骨䯣に集まらず，したがつて Hb 合成が阻害され，その代りに脾に Hemosiderin と して incorporate れれたまま抑留状態をひき起こし， Ferritin および Hb の生合成が抑留されることを 示唆している，同様なととは担癌ラッテにも起つて おり， ${ }^{59 F e}$ の骨への incorporation がさらに減少し， それに代つて肝への incorporationが増加している. このと.とは腫湯から産出される Toxohormon が, 生体の鉄代謝障碍を若起するためであろうと考えら れる、しかしながらてのように絧内系機能の低下し ている担癌ラッテを網内系をブロックするところ の MC で治療すると，担癌ラッテに比へて ${ }^{59 \mathrm{Fe}}$ の incorporationは肝・脾で減少し，骨および腫㿔 で増加し， F/H 宕むかなり増加する傾向かみられ た.とのように担癌ラッテに MC を投与たし場合， 腫瘤の ${ }^{59} \mathrm{Fe} の$ incorporation が增加する所見を得 たが，てれは組織学的にす腫湯に Hemosiderin が 証明されたととからみて Hemosiderose によるもの 
と考えてよく、またとの Hemosiderose は MC が

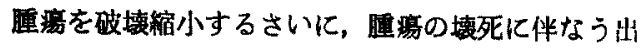
血によるあのが主であろうと考えられる。なおま た Spat Paper Autoradiography で Hb 合成荤延 のみられた第 3 群の No.41 は第 3 群の F/H 6 の

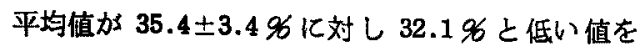
示している．とのように正常ラッテに MC 500 $\mathrm{mcg} / \mathrm{kg} / \mathrm{dag} \times 4$ 日連続投与すると，加なり網内系 がプロックされ，Ferritin の生合成が㸡され， Hemosiderin の抑留をきたしひいては Hbの合 成が著明に阻害あるいは逢延されるような個体があ るということは注目すへきととである。第 4 群すな わち担癌群の No. 55 にも Hb合成遅延がみられた が, $\mathrm{F} / \mathrm{H} \% 6$ は同群の平均値 $36.5 \pm 6.2 \%$ 亿対し 31.596 で第 4 群中最も低く，腫缶の発育す第 4 群中最大であつた。とれは腫璌より産生される Toxohormon により網内系が最もブロックされた 結果であろうと考えられる．また担癌ラッテを MC で治療した第 5 群の No. 62 6 Hb 合成遅延のみら れた例だか，F/H \% は平均值 $41.7 \pm 3.4 \%$ K対 し 39.5 名 と第 5 群中最す低く，腫湯の発育状態 は MC 投与にあ拘らす縮小するととなく最も増大 した例である。これはNo.62では MC がさほど 制癌的に颠かず，腫場を增大せしめ Toxohormon を多量に産出して網内系をブロックしたためである と考えられ，臨床上われわれがしばしば遭遇する制 癌剂偟よる副作用の著明な症例などは，No.62のよ うなととが起つているのかあ知れない.

以上のことから，制癌剂投与時の副作用を防止す るには網内系や骨髄系の賦活を企图することが極め て合目的的であり, Hemosiderin 㧕留防止汇対して あまた骨髄網内系の Hb 合成賦活に対してあ輸血 ならびに輸液が大幅な効果を挙げうるととが慗書き される. この網内系の撰択的倵活剂の探求は，将来 癌治療にとつて重大な意義をあつに至るであるう。

\section{第5 章 詰論}

Mitomycin C 加正常ラッテおよび吉田肉腫皮下 移植ラッテの網内系機能に如何なる影郘を及ばすか を，血清鉄コロイド $59 \mathrm{Fe}$ を用いて実験を行なつた 結果，次のごとき結論を得た。

1）血清鉄コロイド $59 \mathrm{Fe}$ をラッテの屁婙脈汇注
射すると，次第飞血中より減少し，12〜24 時間で 末梢血中より，ほとんど消失するか， その後再び増

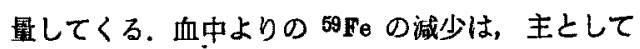
絟内系細胞による頜喰を意味し，てれ机つつく增量 は $69 \mathrm{Fe}$ の Hb への輸入合成を示している.

2）正常ラッテであ，正常ラッテに Mitomycin C を投与したものであ，またラッテに吉田肉腫を皮下 移植したものでも，静注した血清鉄コロイド ${ }^{59} \mathrm{Fe}$ の貪喰能隹差はないか， その後の Hb 合成能 には有意の差があり，Mitomycin C の投与および 吉田肉尰皮下移植により， $\mathrm{Hb}$ 合成能が䢭延ないし 障碍される。

3）あらかじめ吉田肉腄を皮下移植したラッテに Mitomycin C を投与すると, 吉田肉嗹のみ皮下移 植したラッテに比へて，むしろ $\mathrm{Hb}$ 合成能は改善 される。

4) 正常ラッテに Mitomycin C を投与すると, 静注した ${ }^{59} \mathrm{Fe}$ の各臓器への分布は，正常ラッテ群 に比へて脾に多くなり，骨において減少する. 吉田 肉腫を皮下移植すると，肝にやや減少し，骨でも減 少する.

5）あらかじめ吉田内厘を皮下移植したラッテに Mitomycin C を投与すると, 吉田肉腫のみ皮下移 植したラッテに比へて， ${ }^{69} \mathrm{Fe} の$ 分布率は，肝，脾 で減少し，骨，睡煬で增加する。

6) 正常ラッテに Mitomycin Cを投与したり, 吉 时肉腫を皮下移植すると，Ferritin 対 Hemosiderin の此率は减小する。ところが吉田肉腫をあらかじめ 皮下移植したラッテに Mitomycin C を投与すると， この比率はむしろ正常に近ずく。

7）吉田内腫を皮下移植したラッテの缠海は, Mitomycin C $200 \mathrm{mcg} / \mathrm{kg} / \mathrm{day} \times 4$ 日の投与により 一時綃小する傾向を示すが，再び増大する。しいし Mitomycin $0500 \mathrm{mcg} / \mathrm{kg} / \mathrm{dag} \times 4$ 日の投与により, 尰湟は次第に粳小する。

稿を終るКのぞ御指䢘，御校閲を賜わつた陳内 教授に深甚の漱意を表するとともに，本研究につい て種々御指導, 御助言下さつた当教室の小休淳一博 士飞感謝し，またマイトマインンを提供下さつた協 和酸醉株式会社飞感謝する。 


\section{文}

1) 德山：治猗, 42, 79, 1960.

2）盛田：名古屋市大医学会雑誌，9，313，1958.

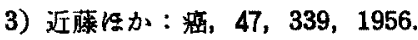

4) 今永：外科, 21, 1045, 1959.

5）建久井：名古屋医学，75，1107，1958.

6) Baillif: RES Bulletin, V, 1, 1960.

7) Halpern: The Proceedings of the Third International Symposium on the Reticuloendothelial System, Ronald Press Co. New York, 1960.

8) Thorell: RES Bulletin, IV, 1958.

9) Bollag: RES Bulletin, I, 1, 1955.

10) Stern: The Procedings of the Third International Symposium on the Reticuloendothelial System, Ronald Press. Co. New York, 1960.

11）小林：日本血液学会雑誌，22，93，1959.

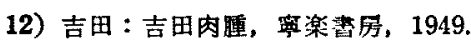

13）吉野：日本医科大学会雑誌，19，395，1952.

14）中島：日本医科大学会雜誌，19，961，1952.

15) Bruckmann and Zondek: J. Biol. Chem., 135,

\section{哮}

23, 1940 .

16) Yoneyama and Konno: The Journal of Binchemistry, 40, 377, 1953.

17) 妹尾：第 8 回国際血液学会網内系ンンボジウム, 1961.

18）赤眗：最新医学，16，300，1961.

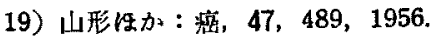

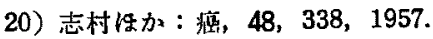

21）久留性か：瘦４8，328，1957。

22) Pillemer, L., etc : Science, 120, 279, 1954.

23) Orita, K. : Acta Med. Okayama, 15, 59, 1960.

24）有賀：日本外科学侌雑誌，61，64，1960.

25）佐藤：綜合䜸床，6，71，1957。

26) Price, V. E., and Greenfield, R. E. : Abstr. 128 th. Meeting Am. Chem. Soc., Minneapolis, 70, 1955.

27) Greenstein, J. P. : Biochemistry of Cancer, 2, $518,1954$.

28）飯島：綜合臨床，6，96，1957.

\section{写真 説明}

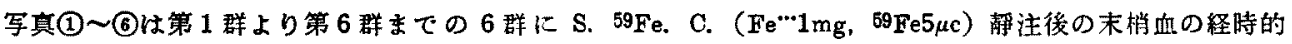
Spot Paper Autoradiograph である.

(1) ${ }^{59} \mathrm{Fe}$ は 12 時間で殆んど末梢血中より減少しているが，24 時間ではすでに Ib 合成が起つている。

(2) ${ }^{59} \mathrm{Fe}$ は 12 時間で殆んど末梢血中ょり減少しているが，48 時間目から $\mathrm{Hb}$ 合成が起つて括り，合成 荤延がみられる。

(3) No. 41 の 72 時間目からようやく合成がみられる程と强度の合成远延がみられるものを含み，一般 に第 2 群よりる强い合成远延がみられる。

（4）第 1 群よりやや合成崌延がみられ，24ないし 48 時間より合成が閏始されている.その内でも No. 53， No. 55 は大巾の㩧延がみられる.

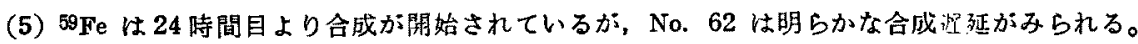

(6) $59 \mathrm{Fe}$ は 24 時間で合成が開始され，第 1 群飞近い成絖を示している。

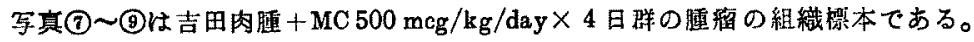

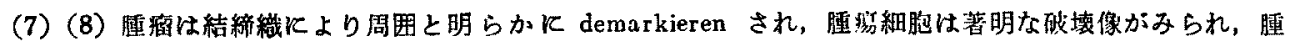
留の中心は壊死飞括ち入り，治痖への過程が証明される。

(9) 周囲の Demarkationszone Kは Hemosiderin の沈着が著明にみられる.（ $\rightarrow$ 四） 


\title{
Anti-cancer Agents and Their Effects
}

\section{Part 3 The Reticuloendothelial System and Anti-cancer Therapy}

\author{
By \\ Hideyuki KAMEYAMA \\ Ist Department of Surgery, Okayama University Medical School
}

(Director: Prof. Jinnai, D. M. D.)

The effectiveness of the Mitomycin $C$ on the reticuloendotherial system is studied in using normal rats and rats with Yoshida-Sarcoma. The serum iron colloid by labelled ${ }^{59} \mathrm{Fe}$ (S. ${ }^{69} \mathrm{Fe}$. C. ) administered intravenously is gradually decreased in the circulating blood, being almost disappeared 12 or 24 hours after administration, followed to be gradually increased later on again.

It has been assumed that the diminition of the ${ }^{59} \mathrm{Fe}$ from the circulating blood results from the colloid phagocytizing function of the reticuloendothelial system and the succeeding increase of the ${ }^{59} \mathrm{Fe}$ does from the $\mathrm{Hb}$ incorporation. But there is no significant difference in the colloid phagocytizing function of the intravenously injected $\mathrm{S}$. ${ }^{\circ 9} \mathrm{Fe}$. C., but in the $\mathrm{Hb}$ incorporation between normal and treated rats with the Mitomycin $\mathrm{C}$ or with the Yoshida-Sarcoma; the $\mathrm{Hb}$ incorporation is delayed or inhibitttd in the treated rats, while rather improved by the administration of the Mitomycin $\mathrm{C}$ to the rats with the tumor.

Of the distribution of the administered ${ }^{5 y} \mathrm{Fe}$, which is increased in the spleen, and decreased in the bone in the normal rats with Mitomycin $\mathrm{C}$ and decreased in the liver in less degree and in the bone in some degree in the rats with the Yoshida-Sarcoma, compared with the normal rats. Whereas the ${ }^{89} \mathrm{Fe}$ is decreased in the liver and spleen, and increased in the bone and neoplistic tissue by the administration of the Mitomycin $\mathrm{C}$ to the rats with the Yoshida-Sarcoma, compared with the rats with Yoshida-Sarcoma alone.

The ratio of Ferritin/Hemosiderin is decreased in the normal rats given Mitomycin $\mathrm{C}$ or inplanted Yoshida-Sarcoma, compared with the normal rats, while this ratio rather approached to tho normal range in the rats with the Yoshida-Sarcoma given Mitomycin C, compared with the Yoshida-Sarcoma alone.

The development of the neoplastic tissue of the rats with Yoshida-Sarcoma has been only temporarily inhibitted with the administration of the Mitomycin C $200 \mathrm{mcg} / \mathrm{kg}$ daily for 4 days. However, gradual but steady inhibition is noted with the closis of $500 \mathrm{mcg} / \mathrm{kg}$ per day for 4 days. 
A 山論 文 附 図

（1）対 照 群

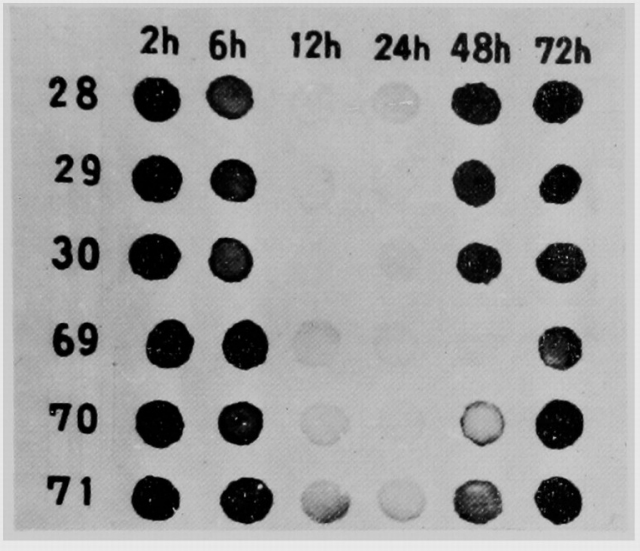

(3) MC $500 \mathrm{mcg} / \mathrm{kg}$ 群

2h $6 h \quad 12 h \quad 24 h \quad 48 h 72 h$

41

$42 \bigcirc$

43

46

47
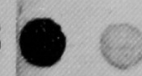

2

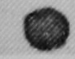

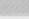

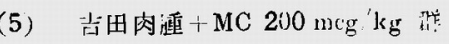

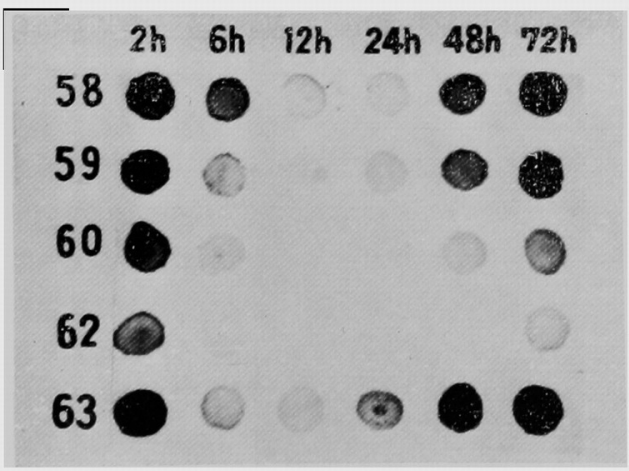

(2) $\mathrm{MC} 200 \mathrm{mcg} / \mathrm{kg}$ 群

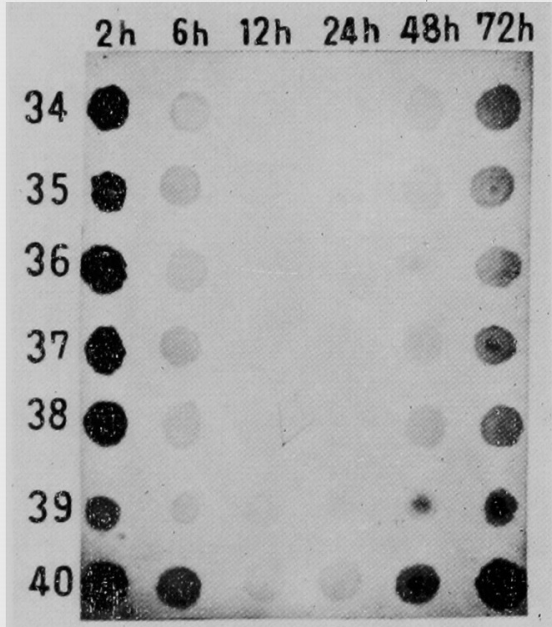

（4）吉田肉連群

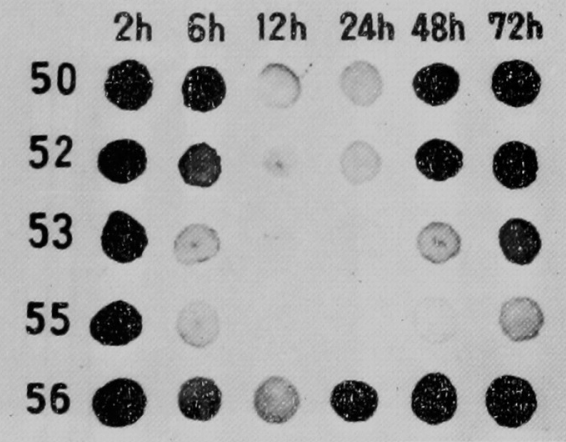

（6）吉回肉堙 $+\mathrm{MC} 500 \mathrm{mcg} / \mathrm{kg}$

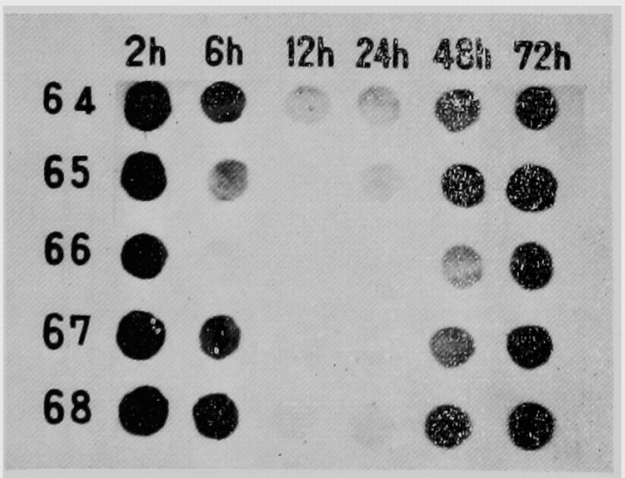


(7)

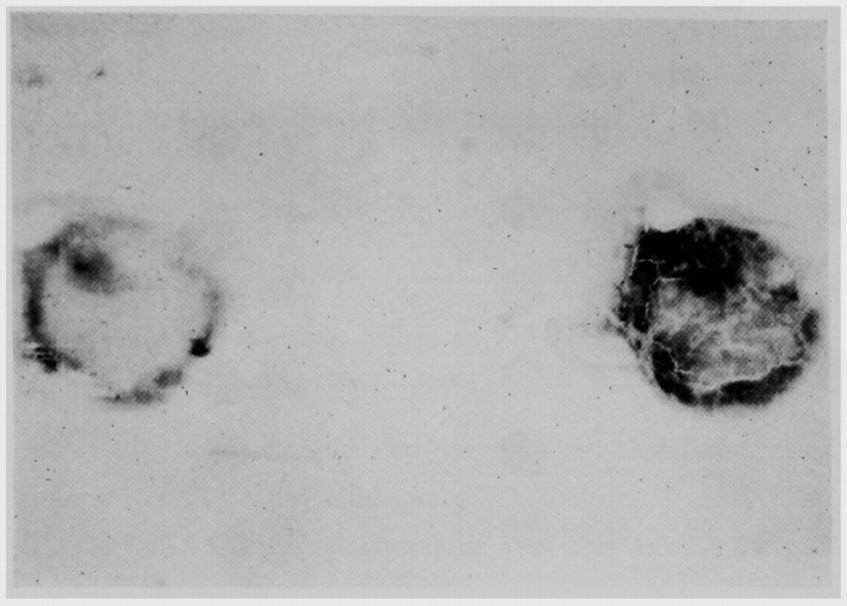

(8)

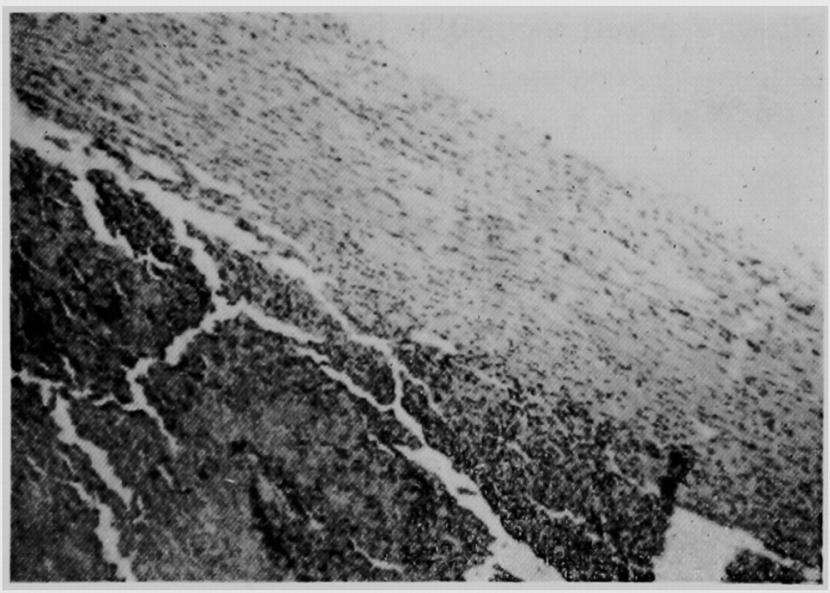

(9)

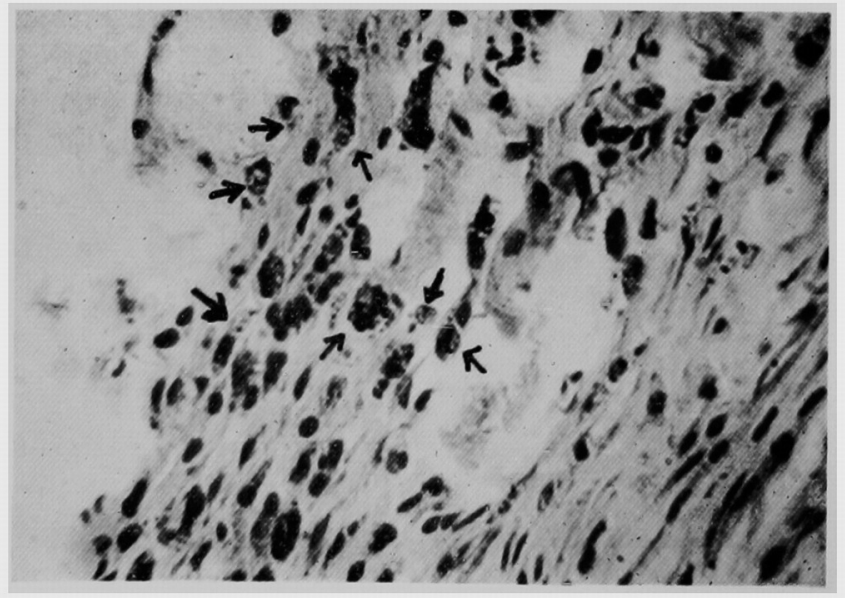

